\title{
DIE DEBAT RONDOM DIE MARKAANSE CHRISTOLOGIE. DIE LAASTE TIEN JAAR ${ }^{1}$
}

C Breytenbach

\section{Abstract}

Marcan Christology: The debate of the last ten years.

The article discusses the developments in the methodological debate on Mark's gospel during the last decade. It shows that the focus in Marcan research shifted from the traditional redactional-historical research towards a literary-critical approach. Some authors also combine the approaches. The author discusses the implications for the Christological debate on the Son of Man and Son of God traditions, with reference to works of Matera, Brower, Hooker, Marcus, Chronis, Motyer, Jackson, Van Iersel and Scharberg, and discerns some prospective avenues for future research.

\section{Inleiding: metodologiese vrae}

\subsection{Die huidige metodologiese diskussie}

Wie die moderne Markusnavorsing dophou, merk spoedig op dat die metodediskussie in 'n sekere sin in die laaste jare aan die stagneer is. Dit gaan hier veral om die diskussie wat aan die tradisionele redaksie-historiese aanpak $^{2}$ aansluit. In 'n sekere sin het die poging om op grond van redaksiekritiek die teks van die Markusevangelie te verklaar, in sy oorsprongland, Duitsland, tot stilstand gekom ${ }^{3}$. Nuwer bydraes uit die protestantse kamp blyk sensitiewer te wees vir die metodeprobleme. Hier kan egter nog nie gepraat word van 'n nuwe aanpak nie 4 . Talle Anglo-Amerikaanse eksegete is tans besig om die bevindinge van "redaktionsgeschichtliche" aanpak binne die Duitse eksegese van die laat sestiger en begin sewentiger jare in die lig van 'n narratologiese aanpak te modifiseer ${ }^{5}$. In die proses is dit duidelik dat die jonger Amerikaanse doctorandi meestal oor die nodige taalkennis beskik om die Duitse debat werklik na te lees en te verwerk. Die redes vir hierdie inten- 
siewe Amerikaanse poging, om die grense van die redaksiekritiek te oorskry, is in die boek van Clifton C. Black II $^{6}$ beskryf. Hy stel die bankrot toestand van die "redaktionsgeschichtliche" metode vas en pleit dat daar meer interdissiplinêre studies moet kom.

Die onvermoë van die redaksie-historiese metode om die teks van die Markusevangelie so te interpreteer dat daar algemeen aanvaarbare bevindinge na vore kom, het daartoe gelei dat prominente Duitse redaksiekritici uit die sewentigerjare al hoe meer begin om die finale teks as vertelling te bestudeer. Die vraag na die tradisie wat Markus dan sou verwerk het, raak nou al hoe meer op die agtergrond 7 . Die tendens om die totale teks as vertelling te bestudeer, is geen nuutjie nie ${ }^{8}$. Met die uitsondering van Dormeyer en Klauck ${ }^{9}$ het die nuwere Duitse navorsing egter eers daartoe oorgegaan om die Markusevangelie ernstig as vertelteks te bestudeer, nadat die belangrike aanvanklike Amerikaanse navorsing in Duits vertaal en gepubliseer is ${ }^{10}$. Daar is egter geen poging by hierdie navorsers om in die huidige metodeproblematiek verder te kom nie. Daar word bloot op die basis wat die Amerikaners gelê het, verder gewerk. Die "literary criticism" aanpak van die Amerikaanse eksegese word binne die tradisioneel histories-kritiese paradigma van die Duitse navorsing opgeneem, sonder om die teoretiese teenstrydighede tussen die twee paradigmata uit die weg te ruim. Die rede waarom daar na Amerikaanse kant vir metodiese alternatiewe gekyk word, lê onder andere by die kritiek teen die "Formgeschichte" wat al hoe ernstiger afmetings begin aanneem. Dit problematiseer een van die grondliggende aannames binne die tradisionele redaksiekritiek, naamlik die hipotese dat Markus vaste vorme uit die mondelinge tradisie redaksioneel verwerk het, aansienlik en ondergrawe so die redaksiekritiese metode.

Soos vermeld, het die hernude poging van die Duitse navorsing om die aandag op die finale teks te vestig, sy metodiese oorspronge in die Verenigde State11. Die aanvanklike impulse wat van die werk van Boomershine ${ }^{12}$, Tannehill, Petersen, $\mathrm{Via}^{13}$ en andere ${ }^{14}$ uitgegaan het, het heelwat Amerikaanse bydraes oor Markus opgelewer ${ }^{15}$. Die invloed van die literêre aanpak en die gepaardgaande vraag na nuwe metodes het intussen ook vrugte in SuidAfrika, ${ }^{16}$ Nederland, ${ }^{17}$ Spanje ${ }^{18}$ en Duitsland ${ }^{19}$ begin dra. Veral die bydraes van Sellin, Van Iersel en Zwick kan as alternatiewe pogings tot die metodedebat gesien word. 
1.2 Die invloed van die metodediskussie op die debat oor die Markaanse Christologie

In die lig van die debat oor die metodologie, is dit verstaanbaar dat daar al hoe meer stemme daarvoor opgaan dat die Markaanse Christologie nar ra to logies bestudeer moet word ${ }^{20}$. Volgens hierdie rigting moet daar gekyk word hoe die verteller Jesus daarstel en watter rol die Christologiese benaminge soos "Christus", "Seun van God", "Seun van die Mens" en "Seun van David" binne die vertelling speel.

Naas hierdie navorsing is daar diegene wat onverpoosd poog om die tradisionele agtergrond van die Christologiese benaminge en uitsprake in die Markusevangelie vanuit die Ou-Testamentiese ${ }^{21}$ en die vroeg-Joodse 22 of vroeg-Christelike 23 tradisie te verklaar. In hierdie verband is dit 'n besondere probleem dat die herkoms en betekenis van die "Seun van die Mens" benaming 24 en die agtergrond van die titel "Seun van God" by Markus ${ }^{25}$ heeltemal omstrede is.

In deel 2 word daar meer intensief op die probleem rondom die bestudering van die Markaanse Christologie ingegaan.

1.3 Die narratologiese aanpak tot die Markusvangelie: 'n dogma of 'n ontvlugting?

Daar is ' $n$ duidelike verskil tussen diegene wat op grond van teoretiese oorwegings die redaksiekritiek as interpretatiewe metode afwys en die narratiewe analise as alternatief voorste ${ }^{26}$ en diegene wat noodgedwonge die narratologiese metodes as 'n verlengstuk van 'n redaksiekritiek, wat net op die eindteks konsentreer, sien, noudat die hele kwessie opnuut geproblematiseer is of 'n mens werklik, soos die vormkritici gepoog het, die voor-Markaanse tradisie kan rekonstrueer. By die eerste groep staan die dogma van die absolute teks wat net binne homself verwys, in die agtergrond. Hulle bestudeer die teks as literêre eenheid wat insigself verwys en vanuit homself verstaan moet word sonder om aandag aan die assosiasies met ekstratekstuele gebeure, persone of plekke te gee wat die hoorders met karakters binne die teks kon verbind het.

By die tweede groep word gepoog om van die nood van die vorm- en redaksiekritiek nou 'n deug te maak. Omdat tradisie so moeilik vasgestel kan word, weet 'n mens nouliks wat geredigeer is. Dit raak al hoe moeliker vir redaksiekritici om die redaksieproses te bestudeer. Party vlug vorentoe en 
begin om slegs die finale teks as redaksieresultaat te bestudeer, sonder om te verklaar hoe die teks ontstaan het. Myns insiens kan die probleem nie so opgelos word nie. Wie sê dat die Markusevangelie 'n teks is wat tradisie opneem, moet ook in staat wees om die oorleweringsproses wat die Evangelies voorafgegaan het, in breë trekke te beskryf. Dit kan slegs gedoen word as daar 'n alternatief tot die "Formgeschichte" se verklaring van hoe die materiaal in die evangelies "voor-literêr" oorgelewer is, gevind word.

In hierdie verband is dit interessant dat daar 'n tussenposisie tussen diegene wat Markus as 'n vertelling en diegene wat Markus as 'n redaksie van tradisie wil lees, aan die onstaan is. Daar bestaan 'n duidelike tendens om Markus as 'n geïntegreerde verhaal te sien wat sterk kenmerke van sy oorspronklike mondelinge agtergrond behou het ${ }^{27}$. Ook hier is daar min duidelikheid oor hoe die stof oorgelewer is voor Markus dit in sy verhaal opgeneem het.

Die hipotese van mondelinge oorlewering voor die skriftelike oorlewering maak sin as 'n mens in ag neem dat Markus vertellings oor dit wat met Jesus gebeur het, as deel van die "evangelie" beskryf (14:9). In die Christelike literatuur verwys die term "evangelie" tot en met die middel van die tweede eeu $\mathrm{nC}$ na die mondelinge proklamasie. Eers na Marcion en Justinus word die term gebruik om na die geskrewe Evangelies te verwys 28 . "Evangelie" is 'n sentrale begrip by Markus $(8: 35 ; 10: 29 ; 13: 10)$. Hy verwys daarmee na die mondelinge oorlewering, die boodskap van die koms van God se koninkryk. Die woorde en die dade van Jesus is vir hom deel van hierdie mondelings oorgelewerde evangelie wat onthou word (14:9).

Hierdie aspek is veral belangrik by die bestudering van die Christologie. Selfs die skerpste kritici van die vormkritik ontken nie dat daar in die vroeëChristendom 'n belydenistradisie bestaan het nie. As die eerste Christene bely het dat Jesus die Here, die Christus, die Seun van God is, moet hierdie belydenistradisie relevant wees vir die verstaan van 'n teks wat binne die vroeë kerk vertel en gehoor is. Om hierdie rede is dit van belang dat die Christologie en die Markusevangelie bestudeer word in die lig van die betekenis wat aan predikate soos "Christus", "Seun van God" en "die Seun van die Mens" in die vroeë Joods-Christelike gemeenskappe geheg is. Dit is myns insiens metodologies onverantwoordbaar om die Christologie vanuit 'n narratologiese hoek teksimmanent te bestudeer soos wat Botha ${ }^{29}$ onlangs in sy proefskrif ${ }^{30}$ wou doen. Aan die ander kant kan dit as feitlik onbestrede geld dat die Markaanse Christologie slegs ondersoek kan word deur daarop te let hoe die verteller Jesus skets ${ }^{31}$. Dit behels egter nie net die mimesis van han- 
deling nie, maar ook dat bepaalde predikate aan Jesus, veral deur God (1:11; $9: 7 ; 12: 6)$ toegeken word. Jesus neem die predikaat "Seun van God" aan (14:62) en op die ou einde neem 'n mens dit op die lippe (15:39). Die verteller verduidelik nie die betekenis van die predikaat nie. Dit word veronderstel. Die betekenis wat die predikaat in verwysing na Jesus gehad het, word deur die vertelling self verder omlyn. Die Christologiese predikate dra egter self ook by tot die betekenis wat hulle binne die narratiewe ontwikkeling kry. By die ondersoek van die Markaanse Christologie kan die narratiewe analise eers tot sy reg kom as die moderne leser 'n toereikende voorstelling van die assosiasies wat die verteller met die "Hoheitstitel" verbind het, kan ontwikkel. Dit kan nie net uit die Markusteks geskied nie.

\section{Die debat rondom die Markaanse Christologie}

\subsection{Inleidend}

Die debat rondom die Markaanse Christologie kan onder drie hoofde daargestel word. Ten eerste het daar heelwat kleiner ondersoeke verskyn wat poog om besondere problematiese tekste soos Markus 9:11-13; 14:61-62 en 15:39 opnuut en op 'n ander manier uit te lê (2.2). Hierdie pogings word dikwels gekombineer met aannames oor die betekenis van benaminge soos "Christus", "Seun van God" en "die Seun van die Mens" in die vroeë Jodedom of voor-Markaanse tradisie. Dit lei daartoe dat sommige navorsers probeer om, op grond van aannames oor die betekenis van 'n bepaalde Christologiese titel, die hooflyne van die Markaanse Christologie te skets (2.3). Vervolgens word die literatuur van die tagtigerjare onder hierdie twee rubrieke bespreek. Weens die enorme omvang van die literatuur kan daar geen aanspraak op volledigheid gemaak word nie. Weens die beperkings op die omvang van hierdie artikel, kan daar slegs op die belangrikste punte van 'n bepaalde voorstel ingegaan word.

\subsection{Nuwe voorstelle vir bekende probleemtekste in Markus}

Vanselfsprekend word hier net gekyk na die probleemtekste wat met die Christologie te make het. Die verhouding tussen Jesus en Johannes die Doper is een van hierdie hoofprobleme. Die eerste teks wat hier ter sprake is, is die proloog Markus 1:1-15. 


\subsubsection{Markus 1:1-15}

$\mathrm{Na}$ sy redaksiekritiese studie oor Markus ${ }^{32}$ het F.J. Matera begin om die Evangelie volgens Markus met behulp van die "literary critical" aanpak te ondersoek. Een van sy eerste studies ${ }^{33}$ gaan oor die proloog van die Evangelie volgens Markus:. Hy vra: "How does the Marcan prologue prepare the reader for the story which follows?"34. Die proloog omvat volgens Matera die verse 2-1335. Die eerste deel (1:2-8) gaan oor die verhouding tussen Jesus en Johannes die Doper. Matera wys daarop dat die leser, anders as die skare, van die begin van die verhaal af weet dat Johannes nie die Messias is nie, maar die voorloper van die Messias. Die proloog gee die leser informasie wat die karakters binne die verhaal nie het nie. In die tweede deel van die proloog (1:9-11) word Jesus geïdentifiseer as die Seun van God wat die volmag van die Gees het.

Once more the reader is privy to inside information essential for understanding Jesus' identity. While the crowds and John see Jesus as another penitent, not even aware that he comes from Galilee, the reader knows that he is the Spirit-empowered Son of God ${ }^{36}$.

Die derde deel van die proloog gaan oor Jesus en Satan. Weer eens word die leser geïnformeer dat Jesus in die mag van die Gees die duiwels weerstaan het. Hulle ken dus die geheim van sy mag oor die duiwels. Matera se literêre studie oor die proloog werp beslis lig op heelwat kernprobleme rondom die Messiasgeheim. Die onderskeiding tussen dit wat aan die leser van die verhaal bekend gemaak word en dit wat die karakters binne die verhaal weet is, alhoewel nie nuut nie, so fundamenteel dat dit goed is dat iemand die belangrikheid daarvan onderstreep het. Matera gaan dan voort om die res van die verhaal in die lig van dit wat in die proloog gesê is, te lees. Nog die godsdienstige leiers nòg Jesus se eie familie of dorpsgenote, nòg die dissipels het begryp wie Jesus is. Eers die Romeinse hoofman het verstaan wie Jesus is. Sy "confession" vorm volgens Matera die klimaks van die verhaal. Al vertel die verteller die leser dat Jesus die Seun van God is, word die betekenis hiervan eers duidelik in die lig van Jesus se kruisdood. Matera ${ }^{37}$ wys in die lig van die werk van Chronis ${ }^{38}$ en Jackson ${ }^{39}$ op die ooreenkomste tussen die proloog en die slottoneel van die kruisiging (15:37-39). Daaroor later (cf infra) 1. Iy wys egter ook daarop dat die verheerliking op die berg die temas van die proloog 
herhaal. Die nuwere studies oor die teks (9:2-13) moet vervolgens bespreek word.

\subsubsection{Markus 9:2-9,11-13; 15:35-36. Jesus, Elia en Johannes die Doper}

In ' $n$ interessante artikel betoog K Brower ${ }^{40}$ dat Markus Jesus deurgaans met Elia paralleliseer. Johannes is Jesus se voorloper. Hy word, soos Jesus, nie verstaan nie en, soos Jesus, moet hy onder die mense ly. Ook Markus 15:3536 pas hierby in. Die gedeelte wys dat die groep om die kruis die rol wat Elia in die gedaante van Johannes die Doper as voorloper van Jesus gespeel het, glad nie verstaan het nie ${ }^{41}$. Die omstanders het nie net Jesus verkeerd gehoor nie. Dit gaan om meer. Die motief dat mense Jesus nie verstaan nie, word hier ook op sy voorloper, Elia aangewend. As die omstanders begryp het dat Elia reeds in die gestalte van Johannes die Doper gekom het, sou hulle nie gedink het dat Jesus na hom om hulp geroep het nie.

Just as they fail to see in Jesus the fulfilment of the messianic role, so they fail to see that in the Baptist the role of the eschatological prophet who must come before the Day of the Lord (Mal. 4:5?) is fulfilled ${ }^{42}$.

M. Hooker ${ }^{43}$ se bydrae toon an dat Markus in die vertelling oor die verheerliking op die berg Jesus met Moses en Elia kontrasteer en uitwys dat Jesus as die Messias (8:29), as Seun van God (9:7), Johannes die Doper, Elia en die profeet in die tradisie van Moses oortref.

J. Marcus ${ }^{44}$ probeer om te verklaar watter uitlegtradisie van die Ou Testament die agtergrond van Markus 9:12 vorm. Hy kom tot die slotsom dat terwyl vers 12a oor Elia na Maleagi 3:22-23 LXX verwys, dit in vers $12 \mathrm{~b}$ om kreatiewe eksegese gaan. Verskillende tekste (Jesaja 52:13-53:12; Daniël 7:13-27 en Psalm 80: 14-17) word hier gekombineer. Dat die "Seun van die Mens" baie moet ly, berus op die interpretasie van die Skrif, eerder as 'n direkte aanhaling. Die grondstuktuur wat agter vers 12 lê, is die volgende. Twee verskillende verwagtings wat albei met ' $n$ beroep op die Skrif gelegitimeer word, word gekontrasteer. Vers $12 \mathrm{~b}$ is ' $\mathrm{n}$ vraag 45 . Marcus vertaal die teks so:

He said to them, "Is it true that, when he comes before the Messiah, Elijah will restore all things? How then has it been written of the Son of Man, that he should suffer many things and be rejected...?"46 
Die antwoord in vers 13 is 'n poging om die klaarblyklike teenspraak tussen verse $12 \mathrm{a}$ en $12 \mathrm{~b}$ te versoen. As dit so is dat Elia voor die Messias moet kom en alles moet herstel, hoe kan die Seun van die Mens, wat volgens Markus die Christus is, baie ly en verwerp word, nog v66rdat Elia alles herstel het? Vers 13 beantwoord die vraag. Die vers veronderstel dat Jesus die Messias as lydende Seun van die Mens is en dat Elia in die gedaante van Johannes die Doper reeds teruggekeer het ${ }^{47}$. As Jesus, die Christus, 'n lydende Christus is, kan Elia as sy voorloper slegs 'n lydende Elia wees. Johannes die Doper pas in die rol.

Marcus (1989a:48) wys verder daarop dat Markus 10:1-9; 12:18-27 en 3537 óók soos 9:11-13 gestruktureer is: Twee skriftuurlike argumente word so gekontrasteer, dat die eerste een met die tweede een versoen word in die lig van die afsluitende opmerking wat gemaak word. Marcus meen dat die evangelis Markus hier 'n midrasj-agtige vorm van argumentasie gebruik het, wat in die Joodse literatuur gebruiklik was en reeds in die Qumrân-geskrifte uitgewys kan word. Vir voorbeelde uit Genesis Rabbah en Levitikus Rabbah beroep Marcus hom op die werk van die bekende Amerikaanse navorser in Judaïstiek, Jacob Neusner ${ }^{48}$. Die bydrae van Marcus is belangrik. Die moontlikheid om sekere episodes uit die Markaanse verhaal in die lig van Joodse argumentatiewe tegnieke, waardeur teenstrydige gesaghebbende tekste met mekaar versoen word, te verklaar, verdien verdere ondersoek.

\subsubsection{Markus 1:9-11 en 15:37-39: Jesus en die Gees}

In 1982 behandel H.L Chronis ${ }^{49}$ die verband tussen Markus 15:38 en die twee omliggende verse 37 en 39 . Hy vra na die funksie wat die "invoeging" op literêre vlak het en kom tot die konklusie dat vers 38 verduidelik waarom die hoofman op grond van Jesus se sterwe tot die uitspraak kom dat Jesus die Seun van God was.

Om hierdie vraag te beantwoord, maak Chronis twee uitgangspunte duidelik. Hy onderstreep eerstens dat dit belangrik is om "Seun van God" reg te verstaan. Anders as die meeste ander Markus verklaarders, meen hy dat die benaming "Seun van God" nie in die lig van die koninklike Messianologie verstaan moet word nie. Met "Seun van God" druk Markus nie uit dat Jesus die Messias is nie. Ook die benaming "Koning van die Jode" is nie 'n sinoniem vir "Messias/Christus" nie. Chronis trek 'n verband tussen die "Koning van die Jode" en die boodskap van God se heerskappy wat die Markaanse Jesus verkondig. Jesus is die verborge koning ${ }^{50}$ van die Jode wat die 
verborge koninklike heerskappy van God verkondig. Maar in watter sin is hy koning? Hy is 'n goddelike koning. Ook die benaming "Seun van God" druk vir Chronis Jesus se goddelikheid uit. Markus veronderstel reeds die Christelike opvatting dat Jesus 'n goddelike wese is ${ }^{51}$. Die tweede veronderstelling van Chronis is dat Markus 'n sterk verband tussen Jesus se identiteit en die tempel trek. Markus 15:38 is deel van dié kompleks.

Die teks van Markus 15:37-37 gee drie aanduidings van hoe die gedeelte verstaan moet word. Die tempelvoorhang word geskeur. Die passief druk 'n handeling van God uit. Die hoofman staan regoor Jesus. Die segswyse wat hier gebruik word (ex enantias autou), sluit aan by "one of the idiomatic expressions for entering the temple, for standing 'in the presence' or 'before the face'of God"52. Die oomblik as die voorhang skeur, gaan die allerheiligste in die tempel oop. Dit is 'n teofanie. Hierdie gebeure word deur Markus as motivering daarvoor gebruik waarom die hoofman erken dat Jesus die Seun van God is. Die Christofanie wat die hoofman sien as Jesus sterf, word so as teofanie gekarakteriseer. Omdat die hoofman God in die gekruisigde Jesus sien, bely hy dat Jesus Goddelik is.

Standing in the presence of the dying Jesus, he feels himself to be standing in the divine 'presence'. Looking into the face of the crucified Jesus at the instant of his death, he sees (as it were) in the very 'face' of God ${ }^{53}$.

Jesus se kruis is die plek waar God teenwoordig is, nie die tempel nie. Verstaan 'n mens Markus 37-39 so, dan word dit duidelik waarom, volgens Chronis, die Markusevangelie die tema "vernietiging en herbou van die tempel" so sterk met Jesus se verwerping en sy ware identiteit verbind. Jesus word as ware tempel verstaan.

Terwyl Chronis Markus 15:37-39 in die lig van die "tempel-tema" interpreteer, het die meeste eksegete in die afgelope jare al meer die verband tussen Markus 1:9-11 en 15:37-39 begin trek ${ }^{54}$. Hier gaan dit nie net daarom, dat in beide tekste Jesus as die Seun van God geproklameer word nie, maar ook om die rol wat Elia, die Gees en die werkwoord schizô in beide perikope speel. Diegene wat volgens 15:35 sê Jesus roep Elia, het die verband tussen Elia en hom nie verstaan nie. Dat Jesus die Seun van God is, hang ten nouste met die Gees saam, wat Hy tydens die doop ontvang het ${ }^{55}$. Wat is nou die inhoudelike implikasie van hierdie ooreenkomste?

T. Motyer meen dat wanneer Jesus sy asem hard uitblaas, die tempel- 
voorhang skeur en 'n heiden bely dat Jesus die Seun van God was, die belofte van Markus 1:8 vervul word. Dit is Markus se manier om van Pinkster te vertel. "The moment of death is the moment at which the Spirit is given"56. So word die beloftes van Markus 1:8 en 13:2 prolepties vervul. Hierdie uitleg is onwaarskynlik. In alle tradisies van die vroeë Christendom volg die uitstorting van die Gees (vgl Romeine 5:5) op die opstanding van Jesus.

In 1987 het 'n ander belangrike opstel oor Markus verskyn. H.M. Jackson vra: "What was it that prompted the centurion's sudden and unexpected confession of Jesus' nearness to divinity?"57 Myns insiens tereg58, betrek hy vers 39 via die houtôs op vers 37 . Die vraag volgens Jackson is egter waarom die harde skreeu waarmee Jesus uitasem as rede vir die belydenis van die hoofman aangevoer word. Volgens hom verklaar die blote uitroep nie waarom die hoofman daartoe oorgaan om Jesus as die Seun van God te bely nie. Om die probleem op te klaar, is dit nodig om daarop te let dat die titel "Seun van God" Jesus as draer van die Gees uitwys. Jesus is die medium waardeur die Gees werk ${ }^{59}$. Die wyse waarop Jesus uitasem, word deur die hoofman "gesien", dit was 'n visuele en auditiewe ervaring60. Wat het die hoofman gesien?

"The soliloquizing centurion ... saw a miracle, and it was God's Spirit in Jesus who worked it. But what was it?"61

Die hoofman het gesien hoe die Gees wat Jesus uitasem, die tempelvoorhang in twee skeur ${ }^{62}$. Hoe kom Jackson daarby uit? Hy betrek die pronomen in vers 39 terug op die tempel in vers 38 en onderstreep dat die verteller eksplisiet meld dat die hoofman op Golgota regoor die tempel gestaan het en gesien het hoe, toe Jesus uitasem, die voorhang voor die ingang van die tempel op die Sionsberg skeur. Dit is natuurlik nie van Golgota af moontlik nie. Jackson postuleer dus dat Markus se voorstelling van die uitleg van Jerusalem nie korrek was nie en hy die ligging van Golgota met die van die Olyfberg verwar het. Vandaar kan 'n mens die tempel sien (Mk 13:2-3). Die Gees van God verlaat Jesus en keer terug na God. In die proses word die oordeel oor die tempel voltrek deurdat die Gees as 'n magtige wind die tempelvoorhang aan die buitedeure in twee skeur en so die eskatologiese mag van God illustreer. Vir Jackson is die kruisiging terselfdertyd die intronisasie van die Seun van God, Hy word verhoog tot God se regterhand. So word die beloftes van Markus 9:1; 13:1-4 en 14:61-62 aan die kruis vervul63. Die hoofman sien dit gebeur. Jesus is die bron van die Gees wat so magtig is, daarom bely hy: "Waarlik, hierdie man was die Seun van God". 
Daar is baie positiewe aspekte in die artikel van Jackson. Die kombinasie tussen die Gees en die Seunskap is (veral in die lig van die doopepisode in Markus 1:9-11) waarskynlik korrek. Die verbintenis tussen die manier wat die Gees Jesus verlaat en die hoofman se belydenis word deur die teks self gelê. Dit is ook belangrik dat Jackson daarop wys dat die Gees van God ook dikwels die instrument van oordeel is ${ }^{64}$. Dit is egter onwaarskynlik dat autou in vers 39 tou naou uit vers 38 opneem en dat Markus wat tog die Olyfberg (13:3) en Golgota (15:22) noem, die twee plekke sou identifiseer.

B. Van Iersel reageer tereg baie positief op die artikel van Jackson 65 en meen dat 1:8 in 15:38 in vervulling gaan as oordeel oor die Jode uit Jerusalem en Judea. Deur die Gees (1:8) straf Jesus diegene wat hulle deur Johannes laat doop het, maar nie tot bekering gekom het nie. Die Gees wat die gekruisigde Seun van God verlaat, skeur die tempelvoorhang en lei so die eskatologiese vernietiging van die tempel in 66 . Die verband tussen Jesus as die Christus, die Seun van God, en die vernietiging van die tempel, speel ook 'n groot rol in die episode oor die verhoor van Jesus in Markus 14:55-6567. Die verband tussen Markus 14:58 en 15:38 kan nog duideliker gestel word as wat D. Lührmann dit doen 68 .

Alle bydraes wat tot dusver bespreek is, het daarvan uitgegaan dat Markus 15:39 positief interpreteer moet word.

E.S. Johnson Jr. 69 betwis dit as hy vra: "Is Mark 15.39 the key to Mark's Christology?" Op grond van die imperfektum in vers 39 oordeel Johnson 70 dat

...Mark intends ên in the centurion's confession to be taken as an observation of something which from an eyewitness perspective is past and gone. "Truly, this man was (before he died) or has been the Son (a son) of God ${ }^{71}$.

Die verdere argumente van Johnson is egter baie problematies. Hy betwis die algemeen aanvaarde interpretasie van vers 39 . Volgens die meeste interpretasies is die uitspraak van die Romeinse hoofman een van die sleutels tot die verstaan van die Christologie van die Evangelie. Johnson meen egter dat 15:39 glad nie die klimaks van die verhaal vorm nie. Die hoofman sê alleenlik Jesus was 'n seun van God. Dit is volgens Johnson buitendien onwaarskynlik dat Markus 'n hoofman oor 'n honderd sou kies om so 'n belangrike uitspraak te maak. Die lesers sou nie kon glo dat 'n geharde Romein so iets sou bely nie. Daarvoor was 'n hoofman oor honderd se sosiale status te hoog, 
sy lojaliteit teenoor die keiser te groot en die kruisingstraf te onwaardig in die oë van die Romeine. Volgens Johnson eindig die Markusevangelie sonder 'n duidelike antwoord uit die kring van die karakters in die verhaal oor wie Jesus was. Nie een van hulle het Jesus reg verstaan nie. Daar is geen sentrale teks wat as dié sleutel vir die Markaanse Christologie kan dien nie.

P.G. Davis ${ }^{72}$ reageer in 1989 op Johnson. Hy wil aantoon dat Markus 15:39 inderdaad die sleutel tot die Markaanse Christologie is. Die rede waarom daar so 'n verskil van mening in die Markaanse debat is, is omdat dié sleutel nie behoorlik gebruik word nie ${ }^{73}$. Of Davis se poging om die Markaanse Christologie te beskryf, geslaagd is, is te betwyfel. Hy meen die grondprobleem van die Markusevangelie is "the divine-human dichotomy"74. Jesus transendeer die humane sfeer, hy transendeer die radikale onderskeid tussen die goddelike en die menslike. As "Seun van die mens" het hy Goddelike outoriteit: "the Son of Man is the man who does what only God can do"75 As "Seun van die Mens" staan Jesus aan God se kant teenoor die mense. Die titel "Seun van God" identifiseer Jesus volgens Davis as 'n Goddelike persoon ${ }^{76}$. Hier word die teks deur die bril van Nicea gelees.

\subsubsection{Markus 12:35-37 en 14:61-62: Wie se seun is die Messias?}

J. Marcus ${ }^{77}$ het die interessante voorstel gemaak dat in Markus 14:61 ho huios tou eulogêtou die Christustitel kwalifiseer. Die twee benaminge is volgens hom nie sinoniem nie:

The second title, "the Son of God," far from being a synonym for "the Messiah," indicates what sort of messianic expectation is in view: not the Messiah-Son-of-David, nor the Messiah as the son of any other human being, but rather the Messiah-Sonof-God ${ }^{78}$.

Marcus wys dan daarop dat daar nog andere voorstellinge van die Messias in die vroeë Jodedom in omloop was: Die Messias as seun van Josef in die rabbynse literatuur, die twee Messiasse van Aäron en Israel in Qumrân. Buitendien, so argumenteer Marcus ${ }^{79}$, Markus 12:35-37 wys dat daar twyfel was oor wie se seun die Messias is. Jesus is die Messias, maar nie bloot as seun van Dawid nie, $\mathrm{Hy}$ is dit as Seun van God. Dit is eers as die Markaanse Jesus sê dat Hy die Seun van God is, dat Hy veroordeel word. Om daarop aanspraak te maak dat iemand Messias is, was geen godslastering nie (Marcus verwys na die geval van Bar-Kogba). Om egter te beweer dat iemand "Seun van God" is, is godslasterlik, soos wat die Lukasteks (Lk 22:70) wys. 
J. Scharberg 80 betoog dat die voorstelling van die merkabah, die strydwa van God (1 Kron 28:18) die agtergrond van Markus 14:62 vorm. Die regters van Jesus sal die Seun van die Mens sittend sien kom. Dit is net moontlik as Hy met die strydwa kom $^{81}$. Sy wys op talle parallelle uit die apokriewe van die Ou Testament en die latere Joodse mistiese literatuur waarvolgens die voorstelling van die heerlikheid en krag van God met die idee van die hemelse troon as strydwa gekoppel is. Hierdie is 'n interessante voorstel wat noukeurig nagegaan behoort te word, veral in die lig daarvan dat die merkabahvoorstelling later in die Jakobus Apokryphon in Nag Hammadi (NHC I 2:14.20-34) en in die Odes van Salomo 38 gebruik word om die verhoging van Jesus te beskryf.

In 'n ewe interessante artikel 82 heropen J. Marcus die debat of peplêrôtai ho kairos na 'n beslissende moment ("appointed time") of eerder na "a span of time" verwys. Op grond van die gebruik van die woord, die Markaanse konteks en vergelykingsmateriaal uit die Joodse (apokaliptiese) literatuur konkludeer Marcus dat dit in Markus 1:15 om die vervulling van "a span of time" 83 gaan. In aansluiting by die apokaliptiek word die vervulde bose tyd wat deur die Satan beheers is, gekontrasteer met die komende tyd. Marcus vat saam:

In Mk 1.15, then, Jesus announces the termination of one age and the beginning of another; he then calls his hearers to turn away from the age that is over and to turn to the age that is beginning ${ }^{84}$.

Tradisie-histories is Markus 1:15 voor-Markaans en familie van die Freerlogion (vgl Mk 16:14). Die evangelis Markus het die woorde uit die doopliturgie van sy gemeente oorgeneem, soos ooreenkomste (vgl Rm 13:12; 1 Ts 5:5-6; Kol 1:13 en Hd 26:18) met die tradisies uit die vroeg-Christelike doopliturgie volgens Marcus wys ${ }^{85}$.

2.3 Tradisie-historiese sleutels tot die verstaan van die Seun van God by Markus.

\subsubsection{Inleiding}

Die tradisie-historiese aanpak tot die verstaan van die Markaanse Christologie het steeds sy uitgangspunt in die sogenaamde "titels" geneem wat Jesus se majesteit sou uitdruk. Die magistrale dissertasie van F. Hahn ${ }^{86}$ het begin as 
'n proefskrif oor die die Christologie van Markus. Tot vandag toe, dertig jaar nadat Hahn sy proefskrif voltooi het, is die misterie van die Markaanse Christologie nog steeds nie opgelos nie. Die debat duur steeds voort. 'n Mens kan hoogstens sê dat die diskussie van die tagtigerjare hier 'n groot ommeswaai beleef het. Twee fundamentele aannames van die diskussie in die sewentigerjare het intussen aan populariteit ingeboet.

Eerstens: Die kommentatore van die jare sewentig was nie bereid om van 'n geintegreerde Markaanse Christologie te praat nie. Markus se Christologie is ' $n$ mosaïek van die Christologieë van sy tradisie wat hy opneem 87 . Die narratologiese aanpak van die tagtigerjare bring mee dat die kommentatore meer na die Christologie van Markus vra ${ }^{88}$.

Tweedens: Sedert W. Wrede 89 is die "Seun-van-God"-titel as die sentrale titel binne die Markaanse Christologie beskou. Terselfdertyd is daar erns daarmee gemaak dat die demone Jesus Seun van God noem in verband met sy wonderwerke. Markus sou - onder sterk invloed van die Griekse denkwyses - deur die benaming "Seun van God" en die baie wonders in sy verhaal veral uitdruk dat Jesus 'n soort goddelike wese is. In die sewentigerjare het die Markusspesialiste hierdie opvatting van "Seun van God" as die uitdrukking van die "goddelike wese" van die Seun binne 'n konflik-model geplaas. Markus neem die wondervertellinge en die opvatting dat Jesus 'n goddelike man (theios anêr) was, uit die gemeenteoorlewering op en kritiseer hierdie opvatting in die lig van die oortuiging dat Jesus net as Seun van God verstaan kan word as daar in ag geneem word, dat hy as "Seun van die Mens" moes ly. Nadat die pogings van die jare sewentig om die Markaanse Christologie binne 'n konflik-model, waarvolgens Markus of sou poog om 'n theios-anêrChristologie teen te staan, misluk het ${ }^{90}$, word na nuwe weë gesoek. Daarvoor is dit egter nodig om die agtergrond en betekenis van die "Seun van God" benaming opnuut te verstaan. Presies op dié punt lê die probleem: daar is nog geen konsensus oor watter assosiasies Markus of sy lesers met die titel "Seun van God" kon verbind het nie. In die volgende uiteensetting stel ons die drie hoofmodelle voor. Elkeen van die modelle vul die titel "Seun van God" anders. Dit het die konsekwensie dat hulle die verband tussen die "Seun-vanGod"- en die "Christus"-titel verskillend opvat.

Die twee hoofstandpunte in hierdie debat word deur D. Lührmann ${ }^{91}$, een van die belangrikste Markus-kommentatore van die tagtigerjare, en deur M. de Jonge ${ }^{92}$ een van die belangrikste navorsers op die gebied van die Christologie van die Nuwe Testament en R. Guelich ${ }^{93}$, die outeur van die belangrikste Engelstalige kommentaar oor Markus, gehuldig. Daar is ook 'n derde standpunt, wat tot dusvêr nog net in kleiner studies voorgestel is ${ }^{94}$. 


\subsubsection{Die Seun van God as die lydende Regverdige}

D. Lührmann het sy standpunt reeds in 1977 gepubliseer en toe in sy kommentaar van 1987 verder ontwikkel. Hy wys daarop dat nóg die Messias nóg 'n ander eskatologiese figuur in die vroeë Jodedom "Seun van God" genoem is. In die Wysheid van Salomo word die lydende regverdige egter dikwels "Seun van God" genoem (Wysheid van Salomo 2:16.18; 5:5. Vgl ook die Psalms van Salomo 13:9; 17:27; 18:4). Volgens Lührmann beklemtoon Markus dat Jesus die lydende Regverdige is, wie sy reg van God self sal kry, wanneer hy Hom Seun van God noem ${ }^{95}$. Daarteenoor is die "Christus"-titel slegs voorlopig. Dit moet in die lig daarvan verklaar word dat Jesus die lydende Regverdige is ${ }^{96}$. "Koning van die Jode" is Jesus as bespotte, lydende en gekruisigde Seun van God97. Lührmann laat hom deur die gebruik van "Christus" in die vroeë Jodedom lei. Dat "Seun van God" daar 'n "Messiaanse" titel is, kan nouliks bewys word. In die Christelike oorlewering (bv Mk 14:61 en Mt 16:16) word die "Seun van God"-titel en die "Christus"titel op mekaar betrek. Hierdie feit kan nie verklaar hoe dit ontstaan het dat die eerste Christene Jesus die "Seun van God" begin noem het nie. In die lig van die verband tussen Markus 8:29 en 9:7 en Markus 14:61-62; 15:32 en in die lig van Matteus en Lukas se interpretasie van die Markustekste, is dit egter werklik onwaarskynlik dat Markus "Seun van God" nie in die lig van die koninklike Messianologie verstaan het nie.

\subsubsection{Die Seun van God as die koninklike Messias}

F. Hahn98 is van mening dat Markus deur die benaming "Seun van God" Jesus se wese uitdruk en deur "Seun van die Mens" sy heilshistoriese funksie (1983a:931; 1983b:1154). Die "Christus"-titel word oorkoepelend gebruik en bind die twee aspekte saam ${ }^{99}$.

M. de Jonge oordeel dat die "Seun van God"-titel vir Markus sentraal is ${ }^{100}$. Markus veronderstel egter reeds 'n Christelike resepsie van benaminge soos "Christus" en "Seun van God". Veral die "Christus"-titel het sy betekenis weens die aanwending daarvan op die gekruisigde Jesus gekry101. Die probleem waarvoor Markus volgens De Jonge staan, is dat die benaming "Christus", byvoorbeeld, self oop vir interpretasie is:

"...calling Jesus 'the Christ' did not necessarily imply a right understanding of him"102. 
Die evangelis skryf in 'n tyd waarin dit nodig geword het om te verduidelik wat dit beteken as Jesus "Christus", "Seun van God" of "Seun van Dawid" genoem word 103 . Hy onderstreep in 8:27-9:1 dat dié wat Jesus as die Christus bely, moet begryp dat $\mathrm{Hy}$ die lydende Christus is en bereid moet wees om Hom op sy lydensweg na te volg. De Jonge kombineer die titels "Christus" en "Koning van die Jode". As Messias is Jesus ook die "Koning van die Jode", maar sy koninklike status is verborge. Dit sal eers by sy parousie openbaar word. Daarom lê daar 'n diepe ironie daarin, as die soldate Jesus as "Koning van die Jode" (15:18) en die Joodse leiers Hom as "Koning van Israel" (15:32) bespot. Hy is dit, maar in verborge, lydende gestalte ${ }^{104}$. Volgens De Jonge depolitiseer Markus die "Christus"-titel in die lig van die Joods-Romeinse oorlog van 66-70 en onderstreep dat die koninklike heerskappy van die Christus eers in die toekoms sal realiseer ${ }^{105}$.

J. Zmijewski106 pak die bestudering van die Markaanse Christologie nog eerder tradisioneel redaksie-krities aan. Hy poog dus om teenoor Pesch ${ }^{107}$, Gnilka ${ }^{108}$ en Ernst ${ }^{109}$ te bewys dat eers die evangelis Markus die "Seun-vanGod"-titel in die oorlewering ingebring het. Sy redaksiekritiese studie kulmineer dan ook in die oordeel dat:

mit grosser Wahrscheinlichkeit erst Mk den Titel "Sohn Gottes" in sein Evangelium eingeführt hat. 110

Daarmee is dit dan ook duidelik dat Markus nie bloot die Christologie van sy tradisies weergee nie, maar 'n eie "Seun-van-God"-Christologie ontwikkel. Vir Zmijewski interpreteer Markus die titel "Seun van God" so dat die wese van Jesus daarmee uitgedruk word. Dit is dus enersyds 'n "Hoheitstitel". Aan die anderkant beklemtoon hy die lydensaspek deur die "Seun van God" uitsprake in die konteks van Jesus se lydensaankondiging (in 8:31) of kruisdood (15:39) te plaas ${ }^{111}$. Die ware wese van Jesus as die verborge Seun van God kan egter eers in die lig van sy lyding verstaan word. Daar is feitlik geen nuwe interpretatiewe insig by Zmijewski nie. In vergelyking met Pesch, Gnilka en Ernst wys sy redaksiekritiese analise egter hoe willekeurig dit is om die vraag of Markus die titel nou ingevoeg, herformuleer of oorgeneem het, tot uitgangspunt vir 'n ondersoek oor die Christologie te gebruik.

\subsubsection{Die Seun van God en die Gees van God}

Metodologies pak M. Theobald 112 die saak anders aan. Alhoewel hy die redaksie-kritiese vrae bly stel ${ }^{113}$, probeer hy om die sinjale in die makroteks, 
wat wys hoe die outeur die verskillende tradisies in sy oorkoepelende konsep geïntegreer het, te eerbiedig.

Kompositionelle Zuordnungen von christologischen Themen und Titeln, Sequenzen einzelner Elemente, die sich wiederholen, mit Bedacht gesetzte Akzente in der Textarchitektur signalisieren die semantischen Orientierungsmarken, die den einzelnen Überlieferungen Maß und Ausrichtung geben, sie in ihren unterschiedlichen Perspektiven zusammenschließen und ihnen so, unbeschadet der Vielgestaltigkeit ihrer je eigenen Tendenzen, den unverwechselbaren Stempel eines übergreifenden Konzepts aufdrücken ${ }^{114}$.

Theobald begin by die tekste waar Markus die "Christus-" en "Seun-vanGod"-titels teenoor die uitsprake in verband met "die Seun van die Mens" stel (8:29,31; 9:7,9; 14:61-62). Hy groepeer die twee titels "Seun van God" en "Christus" saam, omdat Markus na sy oordeel die "Christus"-titel in die lig van die betekenis wat "Seun van God" vir die Markaanse gemeente gehad het, verstaan het 115 . Theobald stel vas dat die eerste deel met Christus of Seun van God in die vorm van 'n belydenis, proklamasie of vraag 'n uitspraak oor Jesus se persoon maak, terwyl die tweede deel 'n uitspraak oor die toekomstige optrede of lot van die Seun van die Mens maak ${ }^{116}$. Dat Jesus die Christus of die Seun van God is, word deur ander bely (of gevra) en het betrekking op die Messiaanse, geesvervulde optrede van die aardse Jesus as die profeet wat die koninklike heerskappy van God aankondig. Jesus se eie uitsprake oor die Seun van die Mens laat die blik op sy dood, opstanding en wederkoms val. Hy praat verhullend van Homself deurdat Hy nóg die Christustitel nóg Seun-van-God gebruik om na homself te verwys, maar in die derde persoon van die Seun van die Mens praat. Dat die benaming "Seun van die Mens" vir Markus geen "Hoheitstitel" is nie en help om Jesus se ware identiteit te verberg, is - alhoewel nie nuut nie (vgl Kingsbury 1983:166) - 'n fundamentele insig. Die werklike funksie van die uitsprake word geensins deur Theobald onderskat nie: daarmee word sentrale soteriologiese funksies wat tradisioneel met God verbonde was (vergewing van sonde [2:10], regter by die eindoordeel $[8: 38 ; 13: 26 ; 14: 62]$ ) aan die Seun van die Mens toege$\operatorname{ken}^{117}$. Die Markusevangelie word gekenmerk deur 'n polariteit tussen die Seun van God/Christus Christologie en die Seun van die Mens soterio logie $^{118}$. Wat beteken dit inhoudelik? 
Die Seun van God Christologie van Markus is volgens Theobald "eine Geistchristologie". Hy toon aan dat verskillende perikope in die Markusevangelie, veral die vertelling oor Jesus se doop, wys dat die titels "Seun van God" en "Christus" in die lig daarvan geïnterpreteer moet word, dat die voor-Markaanse Jesusoorlewering Jesus as die eskatologiese boodskapper van God, wat met die volmag van God se Gees optree, geskets het ${ }^{119}$. In die konteks van die Messiasgeheim kan die belydenis dat Jesus die Seun van God is, eers in die lig van sy lyding uitgespreek word ${ }^{120}$. Hier word die invloede van die Seun-van-die-Mens-Christologie op die pneumatiese Seun-van-God-Christologie duidelik.

Die vraag na die heil van die mens is ten nouste met die Seun van die Mens verbind. Die lyding van die Seun van die Mens het heilsbetekenis (10:45). Die lydensgeskiedenis van Jesus word egter deur Markus in 'n apokaliptiese raamwerk geplaas. Die hoop op die redding in die toekoms is beslissend. Wie in die teenswoordige tyd by die woorde van die Seun van die Mens staan (8:38), sal deur Hom gered word wanneer Hy aan die einde van hierdie kosmos as regter kom $(13: 24-27 ; 14: 62)$.

Benewens Kingsbury ${ }^{121}$ bied Theobald die omvattendste ondersoek oor die Markaanse Christologie in die tagtigerjare. Hy verbind die vraag na die herkoms van die Christologiese opvattinge wat in die Markusevangelie opgeneem is, met die vraag na die integrasie daarvan in 'n oorkoepelende Markaanse konsep. Terselfdertyd probeer hy om, soos De Jonge ${ }^{122}$ die vraag na die historiese konteks van die Christologie nie te ontwyk nie. Sy ondersoek wys egter duidelik dat dit beslissend is hoe 'n mens die "Seun-van-God"-titel vul en hoe 'n mens dit in verband met die "Christus"-titel plaas. Per slot van sake is dit die groot verskil tussen Lührmann, Kingsbury en De Jonge en Theobald en Jackson. Dit is betreurens-waardig dat Theobald slegs die Duitse diskussie oor die Christologie reflekteer. De Jonge en Kingsbury se werk word nie eers genoem nie en die Britse debat oor die Seun van die Mens het ongesiens by Theobald verbygegaan.

\subsubsection{Prospektus}

Die "Seun-van-God"-titel is ten nouste met die "Geheim van God se Seun" in die Markusevangelie verbind. Dit het intussen duidelik geword dat daar tussen dit wat die verteller die leser oor Jesus se identiteit meedeel en dit wat die karakters in die verhaal weet, onderskei moet word ${ }^{123}$. Die leser is deur die verteller in die geheim ingelei, en in 1:11 bevestig God self die perspektief ${ }^{124}$. Die tweevlakkigheid van die "Gottessohngeheimnis" moet in ag geneem word. 
Tweedens moet die verband tussen die geheim van die Seun van God en die geheim van die koninkyk van God (Mk 4:11) in ag geneem word. Eskatologie en Christologie word ook in die jongste diskussie te maklik ontkoppel.

Derdens moet die agtergrond van Markus se voorstelling van die verborge Seun van God ondersoek word. Dit gaan hier om Jesus se identiteit. Die manier waarop die verteller van Jesus as Seun van God vertel, kan nouliks in die lig van die tradisies oor die lydende Geregverdigde behoorlik verklaar word ${ }^{125}$. Die koninklike Messianologie bied die breë agtergrond ${ }^{126}$. Benewens die vraag na moontlike konnotasies met die Joodse "Messianologie"127, is die vraag egter wat Joodse Christene soos Markus en 'n deel van sy gemeente daaronder verstaan het. Tot op datum ${ }^{128}$ is die verband tussen die Gees en die Gesalfde (Christus), tussen die Gees en die Seun van God, nie in die lig van die vroeg-Joodse tradisies oor die koninklike Messias ${ }^{129}$ bekyk nie. Hier lê moontlikhede.

Vierdens moet die verband tussen die "Seun van God" en "die Seun van die Mens" in die ontvouing van Markus se verhaal in ag geneem word ${ }^{130}$.

\subsection{Die Seun van die Mens}

\subsubsection{Inleiding}

Die probleem rondom "die Seun van die Mens" by Markus is ook nog nie uitgepluis nie. Aanvanklik het vele navorsers aangeneem dat "die Seun van die Mens" as titel deur Markus gebruik is. Hierdie standpunt word tans nog gehandhaaf, maar ondertussen het twee ander voorstelle die lig gesien. Die agtergrond van die debat lê veral daarin dat daar nuwe lewe in die debat gekom het of "die Seun van die Mens", wat 'n vertaling uit die Aramees is, ooit in Aramees as 'n titel gebruik is. Die meeste kenners van die antieke Aramees meen dat die vorm bar 'enâshâ' (Grieks huios anthrôpou) gewoon " 'n mens", "iemand", "lid van die menslike ras" beteken. Ook in Daniel 7:13 word die uitdrukking generies gebruik: "iemand soos 'n menseseun (=iemand soos 'n mens)". Hierdie generiese gebruik kom ook in die Aramese tekste, wat by Qumrân gevind is, voor ${ }^{131}$. Daar is onder andere 'n groep Britse navorsers wat meen dat "seun van die mens" (bar nâsh') in Aramees ook as omskrywing vir die persoonlike voornaamwoord in die eerste persoon (ek, my) gebruik is ${ }^{132}$.' $n$ Verdere probleem is dat daar groot meningsverskil daaroor bestaan of die voorkoms van die benaming "Seun van die Mens" in die Etiopiese Henogboek van so 'n aard is dat dit as agtergrond vir die verklaring van die gebruik van die Seun van die Mens by Markus kan 
dien. Aan die een kant is daar nog steeds uitnemende kenners van 1 Henog wat meen dat die boek 'n "Messianologie" bevat wat die Seun van die Mens uit Daniël 7, die lydende Geregverdigde uit Deutero-Jesaja en die Messias binne 'n oorkoepelende apokaliptiese konsepsie met mekaar verbind ${ }^{133}$. Vanuit 'n ander hoek word die titulêre gebruik van Seun van die Mens en Christus in 1 Henog betwis. Een probleem is egter intussen opgelos. Die tendens om gelykenisse (wat onder die Qumrân fragmente ontbreek) in 1 Henog (37-71) in die derde eeue $\mathrm{nC}$ te dateer en so vir die Nuwe-Testamentiese probleme opsy te skuif, is iets van die verlede. Die gelykenisse het 'n Joodse oorsprong en word teen die einde van die eerste eeu $\mathrm{nC}$ gedateer ${ }^{134}$. Dit is egter moontlik dat die tradisies wat hier opgeneem is, reeds vroeër in omloop was. Die hele Seun-van-die-Mens-debat is goed opgesom en dit is onnodig om dit alles hier te herhaal135. Die debat is binne die konteks van hierdie navorsingsoorsig net in so verre relevant, as dat daar gekyk moet word na die konsekwensies wat hierdie debat vir die verstaan van die Markaanse teks het.

Ter wille van duidelikheid stel ek my eie standpunt kortliks. (1) Ongeag of 'n mens nou saam met Vermes' 136 aanvaar dat bar 'enâshâ' as omskrywing vir die eerste persoon gebruik word of nie, 137 is dit onbestrede dat die uitdrukking in die Aramees na "'n mens" of "iemand" verwys. Die probleem is egter dat die Aramees nie tussen gedetermineerd en nie gedetermineerd onderskei nie. Die Griekse uitdrukking in die Evangelies is egter dubbel gedetermineerd: die Seun van die Mens. (2) Daar bestaan ook konsensus daaroor dat bar nâsh'/nâshâ' nêrens in die Joodse Aramees as 'n titel gebruik word nie. In Daniël 7:13 word dit generies binne 'n vergelyking gebruik. In die Latynse vertaling van 4 Esra 13:3 is die passus uitgelaat, maar selfs in die Siriese vertaling kan daar ook nie sprake van 'n titulêre gebruik wees nie. Op die meeste kan 'n mens sê dat die beeld van iemand soos 'n mens uit Daniël 7 nou op ' $n$ indiwidu toegepas word. Dis hoogs waarskynlik dat in die Etiopiese Henogboek geen titulêre gebruik voorkom nie en dat Seun van die Mens hier net voorkom wanneer Daniël 7 die agtergrond vorm. Die bewyslas daarvoor dat daar in die vroeë Jodedom 'n geïntegreerde apokaliptiese "Menschensohnvorstellung" was, lê by diegene wat dit aanhou propageer ${ }^{138}$. Ekself kan tans nie standpunt inneem nie, omdat ek geen Etiopies kan lees nie. (3) Daar waar parallelle vertalings is, by die targumim op Gen 4:14 en by etlike sinoptiese spreuke ${ }^{139}$, is dit duidelik dat die eerste persoon die uitdrukking "die Seun van die Mens" kan vervang (et vice versa), daarom moet 'n mens Fitzmyer ${ }^{140}$ se skepsis teenoor Vermes ${ }^{141}$ nie noodwendig deel nie. 
(4) Die waarskynlikste verklaring vir die ontstaan van die Seun van die Mens spreuke is dat Jesus daarmee na Homself verwys het en dat hierdie spreuke in die lig van die opstandingsgeloof met die hulp van die interpretasietradisie van Daniël 7 (1 Henog kan hiervoor 'n voorbeeld wees) herinterpreteer is ${ }^{142}$. Die Seun van die Mens spreuke wat sy regterlike funksie tematiseer, veronderstel die geloof in die opwekking en verhoging van die Gekruisigde. So ontstaan die dubbel gedetermineerde Griekse uitdrukking met verwysing na die verhoogde se eskatologiese funksie as regter en redder. Markus het 'n beslissende bydrae tot die apokaliptiese interpretasie van die Seun van die Mens-woorde gelewer, soos in Markus 8:38; 13:26 en 14:62 gesien kan word. (5) Die benaming Seun van die Mens is nie 'n Christologiese titel, soos Seun van God of Christus nie. Nêrens word Jesus as Seun van die Mens bely of verkondig nie. Die benaming word gebruik om na Jesus te verwys wanneer sy heilshistoriese funksie beskryf word.

\subsubsection{Die Seun van die Mens in die Markusevangelie}

In 1983 pas B. Lindars ${ }^{143}$ sy teorie oor die gebruik van "die Seun van die Mens" ook op Markus toe. In die lig van die debat tussen Vermes en Fitzmyer gee Lindars toe dat Jesus nie die uitdrukking gebruik het as omskrywing vir "ek" nie. Hy meen egter die uitdrukking word idiomaties gebruik in 'n situasie waar die spreker na 'n groep persone verwys waarby hy homself insluit. Hy parafraseer dan die uitdrukking as "a man such as I" of "a man in my position"144. Jesus sou dit gebruik het as 'n verhullende manier om na Homself te verwys (bv by Mk: Mk 2:10; 8:38; 8:31; 9:31; 10:33). Die gedetermineerde Griekse vorm van die term het die funksie van "an exclusive selfreference"145. Markus gebruik nou die vyf bogenoemde outentieke Jesuswoorde om sy Christologie te onwikkel. Hy skep nuwe spreuke in die lig van Daniël 7:12-14 (vgl Mk 13:26; 14:62) deurdat hy die lydende Jesus met die apokalitiese figuur van Daniel 7:13 wat soos 'n Seun van 'n mens is, geïdentifiseer het ${ }^{146}$. Die oorspronklike spreuk in Markus 8:38 word in die lig van Daniël herinterpreteer en 2:28 word na analogie van 2:10 gevorm. Hierdie manier waarop Jesus na Homself verwys, het self egter geen spesifieke Christologiese inhoud nie. Dit is die konteks waarbinne dit gebruik word wat iets oor Jesus laat blyk. Omdat dit egter'n verhullende manier van selfreferensie is, pas dit uitstekend in die Markaanse konsep van die Messiasgeheim in. Alhoewel daar heelwat kritiek teen Lindars ingebring kan word ${ }^{147}$, bly sy bydrae een van die weiniges wat die Seun van die Mens problematiek in die Markusevangelie nuut aangepak het. 
D. Lührmann ${ }^{148}$ verwys nie eers na die Brits-Amerikaanse-debat nie! Hy probeer met goeie argumente 'n saak daarvoor uitmaak dat Markus alle uitsprake wat oor die lyding van die Seun van die Mens gaan, redaksioneel geskep het $(8: 31 ; 9: 31 ; 10: 33 ; 14: 21,41,62)$ om die die lydensgeskiedenis met die aktuele verwagting van sy gemeente, dat die Seun van die Mens aan die einde van die tyd gaan kom, te verbind ${ }^{149}$.

Die rol wat die "Seun-van-die-Mens"-benaming in die Markusevangelie speel, is sedert N. Perrin ${ }^{150}$ nog nie weer diepgaande ondersoek nie. Dit wil ook nie lyk asof die diskussie intussen verder is nie. Die bydraes van Perrin val egter buite ons tydsbestek ${ }^{151}$.

L. Schenke ${ }^{152}$ se ondersoek van die vertelde Christologie in die Markusevangelie sien met "Seun van God" Jesus se Goddelike, bonatuurlike wese getipeer. Seun van die Mens sou op sy menslikheid wys ${ }^{153}$. Hierdie verklaring is net so onwaarskynlik as Schenke se standpunt dat die Markaanse Christologie pre-eksistensie veronderstel.

\subsubsection{Die Seun van God en die Seun van die Mens in die Markusevangelie}

Die omvattendste boek oor die Markaanse Christologie kom van J.D. Kingsbury ${ }^{154}$. Kingsbury verwerk die debat sedert Wrede en reken veral af met die "korrektiewe" Christologie wat in die sewentigerjare so populêr in die Amerikaanse navorsing was (Weeden e.a.). Die groot voordeel van Kingsbury se studie is dat hy die vraag na die verhouding van die gebruik van die titels "Seun van God," "Christus","Seun van Dawid", "Koning van die Jode", "Koning van Israel" aan die een kant, tot die gebruik van "die Seun van die Mens" by Markus probeer bepaal. Terselfdertyd neem hy die diskussie rondom die Messiasgeheim en die kritiek teenoor Wrede op. Daar ek elders vollediger op Kingsbury ingaan ${ }^{155}$, word hier slegs 'n kort samevatting gegee.

Kingsbury ondersoek die Christologie van die Markusevangelie narratologies. Hy onderskei dus duidelik tussen die standpunt wat die verteller huldig en aan sy leser probeer oordra en die menings wat mense binne die verhaal oor Jesus het. In die lig van die belangrike rol van die Goddelike perspektief in die perikoop oor die doop en die verheerliking op die berg, is dit duidelik dat die titel "Seun van God" die identiteit van Jesus korrek uitdruk. Soos Steichele, De Jonge en Guelich, is Kingsbury van mening dat Markus die titel "Seun van God" in die lig van die koninklike Messianologie verstaan. Kingsbury maak dan ook vryelik gebruik van die vergelykingsmateriaal wat in die tradisie-historiese ondersoeke geakkumuleer is. Die "Seun van God" is "the royal Son of God". Met hierdie groep titels "Seun van 
God", "Christus", "Seun van Dawid" en "die Koning van Israel/die Jode" word Jesus se identiteit meegedeel. "Seun van God" word daarby sterk op die kruis betrek en interpreteer "Christus", "die Seun van David" en "die Koning van Israel/die Jode". Met "die Seun van die Mens" word niks oor die identiteit van Jesus gesê nie, dit sê nie wie Jesus is nie, maar dit beskryf sy "ministry". Sy aardse optrede, sy lyding, dood, opstanding en wederkoms word deur Homself met hulp van die "public title" aan die mense in die verhaal verduidelik. Om hierdie rede ondermyn die gebruik van "die Seun van die Mens" ook nie die konsistensie van die Messiasgeheim nie. Die twee Christologiese perpektiewe (die koninklike Seun van God en die Seun van die Mens) is komplementêr. Terwyl "die Seun van God" die fokus na binne, op Jesus se identiteit plaas, vorm die "die-Seun-van-die-Mens"-tema die buiteperspektief. Dit verduidelik die relasie tussen Jesus en die wêreld. Die ooreenkomste tussen die opvattings van Hahn en Kingsbury is merkwaardig en die herdefinisie van die gebruik van die Seun van die Mens by Markus is 'n duidelike winspunt. Dit is jammer dat Kingsbury die hele vraag na die konnotasie wat die "titels" by die lesers van Markus sou kon oproep heeltemal ignoreer. So word dit baie moeilik om die Markusevangelie binne die konteks van die vroeë Christendom te verstaan. In hierdie opsig het sy poging nie dieselfde oortuigingskrag as dié van De Jonge nie.

\subsubsection{Prospektus}

Die hele stryd oor die herkoms van "die Seun van die Mens" in die evangelies is tans nog onbeslis. Die aard van die "Seun van die Mens" konsep in 1 Henog is omstrede. Dit is omstrede of bar 'nâshâ as plaasvervanging vir die eerste persoon gebruik kan word. Indien wel, en indien dit ook vir ho huios tou anthrôpou geld, dan kan alle gevalle by Markus maklik verklaar word, want dan gebruik Markus die uitdrukking om Jesus verhullend na Homself te laat verwys. Dan is dit deel van die Messiasgeheim en is dit onnodig om verder na die agtergrond van die "titel" "die Seun van die Mens" in die Joodse apokaliptiese literatuur te soek. Markus het dan vanuit die perspektief dat Jesus opgestaan het, die "die- Seun-van-die-Mens"-tekste in die lig van Daniël 7:13 interpreteer (8:38 en 13:26) of as deel van sy vertelling gevorm (14:62). Die Markaanse gebruik van "die Seun van die Mens" kan dus goed in funksionele terme verklaar word, soos wat Kingsbury voorgestel het.

Indien "ho huios tou anthrôpou" egter meer as net 'n verhulde omskrywing vir die spreker is, moet 'n mens weet met watter assosiasies die term in die vroeë-Jodedom gebruik is. In hierdie opsig is die gebruik in 1 Henog be- 
slissend, want 4 Esra 13 reflekteer Daniël 7 eers ná 70 nC. Dit alleen kan nie bewys dat daar 'n algemene individuele interpretasie van Daniël 7 was wat die sinoptiese oorlewering beïnvloed het nie. Die Henog verklaarders kom egter tot geen eenduidige standpunt oor die Seun van die Mens in die Henogboek nie. Alvorens hier nie 'n relatiewe konsensus is nie, is die invloed van die sogenaamde apokaliptiese Seun van die Mens op die sinoptiese oorlewering en op Markus nie wetenskaplik te bespreek nie.

NOTAS:

1 Die finansiële ondersteuning van die INO van die RGN vir hierdie navorsing word hiermee erken. Die menings wat in hierdie publikasie gehuldig word, asook die bevindinge van die ondersoek, is dié van die outeur en mag nie noodwendig as dié van die INO of die RGN aangesien word nie.

2 C Breytenbach, Nachfolge und Zukunftsenwartung nach Markus: Eine methodenkritische Studie, Zürich 1984; S P Kealy, Mark's gospel: $A$ history of its interpretation: From the beginning until 1979, New York 1984.

3 Vgl egter die bydraes uit katolieke kamp van H Giesen, "Christliche Existenz in der Welt und der Menschensohn: Versuch einer Neuinterpretation des Terminwortes Mk 13,30", $S N T U$ vol 8 (1983), 18-69; idem, "Der Auferstandene und seine Gemeinde: Zum Inhalt und zur Funktion des ursprünglichen Markusschlusses (16,1-8)", SNTU vol 12 (1987), 99139; T Söding, Glaube bei Markus, Stuttgart 1985; J Zmijewski, "Die Sohn-GottesPrädikation im Markusevangelium: Zur Frage einer eigenständigen markinischen Titelchristologie", SNTU 12 (1987), 5-34; W Rebell, "Sein Leben Verlieren' (Mark 8,35 Parr.) als Strukturmoment vor- und nachösterlichen Glaubens", NTS vol 35 (1989), 202-218.

4 R Feldmeier, Die Krisis des Gottessohnes: Die Getsemaneerzählung als Schlüssel der Markuspassion, Tübingen 1987.

5 Vgl. B Buby, "A Christology of relationship in Mark", BTB vol 10 (1980), 149-154; H M Jackson, "The death of Jesus in Mark and the miracle from the cross", NTS vol 33 (1987), 16-37; E S Johnson Jr, "Is Mark 15.39 the key to Mark's Christology?", JSNT vol 31 (1987), 3-22; F J Matera, The kingship of Jesus: Composition and theology in Mark 15, Chico 1982; ibid, "The prologue as the interpretative key to Mark's gospel", JSNT vol 34 (1988), 3-20; J Muddiman, The glory of Jesus, Mark 10:37, in L D Hurst \& N T Wright (eds.), The glory of Christ in the New Testament: Studies in Christology: In memory of George Bradford Caird, Oxford 1987, 51-58.

6 C C Black, The disciples according to Mark: Markan redaction in current debate, Sheffield 1989.

7 D Dormeyer, "Die Kompositionsmetapher 'Evangelium Jesu Christi, des Sohnes Gottes' 
Mk 1.1: Ihre theologische und literarische Aufgabe in der Jesus-Biographie des Markus", NTS 33 (1987), 452-468; A Lindemann, "Die Erzählung der Machttaten Jesu", in Anfäge der Christologie (Festschrift fur Ferdinand Hahn zum 65. Geburtstag, herausgegeben von C Breytenbach \& H Paulsen), Göttingen 1991; D Lührmann, "Biographie des Gerechten als Evangelium: Vorstellungen zu einem Markus-Kommentar", $W u D$ NF vol 14 (1977), 25-50; idem, "Markus 14, 55-64: Christologie und Zerstörung des Tempels im Markusevangelium", NTS vol 27 (1981), 457-474; L Schenke, Das Markusevangelium. Stuttgart 1988; M Theobald, "Gottessohn und Menschensohn. Zur polaren Struktur der Christologie im Markusevangelium", SNTU vol 13 (1988), 37-97.

8 W Wrede, Das Messiasgeheimnis in den Evangelien, Göttingen 1901.

9 D Dormeyer, Der Sinn des Leidens Jesu: Historisch-kritische und textpragmatische Analysen zur Markuspassion, Stuttgart 1979 en H J Klauck, "Die erzählerische Rolle der Jünger im Markusevangelium", NT vol 24 (1982), 1-26.

10 Vgl F Hahn (Hg.), Der Erzähler des Evangeliums: Methodische Neuansätze in der Markusforschung, Stuttgart 1985 en die "Wirkungsgeschichte" van hierdie opstelle by D Lührmann, Das Markusevangelium, Tübingen 1987, 20-24; L Schenke, $a$ w, 1988 en A Lindemann, $a w, 1991$, vn 21.

11 Vgl Breytenbach, aw, 54-68.

12 T E Boomershine, Mark the storyteller: $A$ thetorical-critical investigation of Mark's passion and resurrection narrative, New York 1974.

13 Vgl Breytenbach, $a w, 54-65$.

14 D Rhoads \& D Mitchie, Mark as Story: An introduction to the narrative of a Gospel, Philadelphia 1982.

$15 \mathrm{Vgl}$ M A Beavis, "The trail before the sanhedrin (Mark 14:53-65): Reader response and Greco-Roman readers", $C B Q$ vol 49 (1984), 581-596; R M Fowler, "Who is "the reader" of Mark's Gospel?", SBL Seminar Papers, 1983, 31-53; J D Kingsbury, The Christology of Mark's Gospel, Philadelphia 1983; J L Magness, Sense and absence: Structure and suspension in the ending of Mark's Gospel, Atlanta 1986; E S Malborn, "Fallable Followers: Women and men in the Gospel of Mark", Semeia vol 28 (1983), 29-48. Vgl ook R A Guelich, Mark 1-8:26, Dallas 1989, xxii-xxiv.

16 W S Vorster, "Mark: Collector, redactor, author, narrator?", JThSA vol 31 (1980), 46-61; idem, "Die Evangelie volgens Markus: Inleiding en teologie", in A B du Toit (red), Handleiding by die Nuwe Testament, IV: Die Sinoptiese Evangelies en Handelinge: Inleiding en teologie, Pretoria 1980, 109-155; idem, "The New Testament and narratology, JLS / TLW vol 2 (1986), 52-62; idem, Characterization of Peter in the Gospel of Mark", Neotestamentica vol 21(1987), 57-76; idem, "Oor die Nuwe Testament, vertelkunde en prediking", HTS vol 44 (1988), 164-177. 
17 B M F van Ierscl, "Locality, structure and meaning in Mark", LingBibl vol 53 (1983), 44554; idem, "He will baptize you with Holy Spirit (Mark 1,8): The time perspective of baptisei", in T Baarda et al (eds), Text and testimony (Essays on the New Testament and A pocryphal Literature in honour of A F J Klijn), Kampen 1988.

18 C Bravo, Mancos: namativa teologica del conflicto: La respuesta de Dios al pobre (Ensayo de relectura sincronica del relato), Diss. Facultad de teologia, section Francisco de Borja 1984. (Non vidi.)

19 G Sellin, "Textlinguistische und semiotische Erwägungen zu Markus 4,1-34", NTS vol 29 (1983), 508-530; idem, "Einige symbolische und esoterische Züge im MarkusEvangelium", in: Jesu Rede von Goll und ihre Nachgeschichte im frühen Christentum: Beiträge zur Verkündigung Jesu und zum Kengma der Kinche (Festschrift für Willi Marxsen zum 70. Geburtstag, Herausgegeben von D A Koch, G Sellin, A Lindemann), Güthersloh 1989; Breytenbach, a w, 1984; R Zwick, Montage im Markusevangelium: Studien zur narrativen Organisation der ältesten Jesuserzählung, Stuttgart 1989.

20 Vgl R H Fuller, "Mark as narrative Christology", in R H Fuller \& P Perkins (eds), Who is this Christ?, Philadelphia 1983, 67-80; Kingsbury, a w, 1983; M E Boring, The "Christology of Mark: hermeneutical issues for systematic theology", Semeia vol 30 (1984), 124-147; L Chouinard, "Gospel Christology: A study in methodology", JSNT vol 30 (1987), 21-37; Matera, JSNT vol 34 (1988); Schenke $a w, 106-117$; tot 'n mate ook Theobald, SNTU 13 (1988).

21 M Black, "The theological approbation of the Old Testament by the New Testament", SJTh vol 39 (1986), 1-17; M D Hooker, "'What doest thou here, Elijah?': A look at St Mark's account of the transfiguration", The glory of Christ in the New Testament: Studies in Christology (In memory of George Bradford Caird, edited by L D Hurst \& N T Wright), Oxford 1987, 59-70.

22 B Lindars, Jesus Son of Man: A fresh examination of the Son of Man sayings in the Gospels in the light of recent research, London 1983; $M$ de Jonge, The earliest use of Christos. Some suggestions", NTS vol 32 (1986), 321-343; J Marcus, The mystery of the kingdom of God, Atlanta 1986; idem, "Mark 9,11-13: 'As it has been written', ZNW vol 80 (1989), 42 63; idem, "Mark 14:61: 'Are you the Messiah-Son-of-God?', NT vol 31 (1989), 125-141; idem, 'The time has been fulfilled!' (Mark 1.15), in The glory of Christ in the New Testament: Studies in Christology (In memory of George Bradford Caird, edited by L D Hurst \& N T Wright), Oxford 1987, 49-68; J Scharberg, "Mark 14,62: Early Christian Merkabah Imagery?", in Apokalyptic and the New Testament (Essays in honour of $\mathrm{J}$. Louis Martyn, edited by J Marcus \& M L Soards), Sheffield 1989, 49-68.

23 L Hartman, "Taufe, Geist und Sohnschaft: Traditionsgeschichtliche Erwăgungen zu Mk 1,9-11 par.", STNU vol 1 (1976), 89-109; H Klein, "Das Bekenntnis des Petrus und die Anfänge des Christusglaubens im Urchristentum", EVTh vol 47 (1987), 176-192.

24 Vgl die debat by J R Donahue, "Recent studies on the origin of the "Son of Man" in the Gospels", $C B Q$ vol 48 (1986), 484-498; A Vögtle, "Eine überholte "Menschensohn"- 
Hypothese?", in Wissenschaft und Kirche (Festschrift fur E Lohse, herausgegeben von K Aland \& S Mcurcr), Biclefeld 1989, 70-95.

25 Vgl Lührmann, WuD NF vol 14 (1977); idem, a w, 1987; De Jongc, NTS vol 32 (1986).

26 Vorster, Neotestamentica vol 21(1987); Kingsbury $a$ w, 1983.

27 Vgl C Brcytenbach, "Das Problem des Übergangs von mündlicher zu schriftlicher Überlieferung", Neotestamentica vol 20 (1986), 47-58; E Best, "Mark's narrative technique", JSNT vol 37 (1989), 43-58.; J Dewcy, "Oral methods of structuring narrative in Mark", Interp. vol 43, (1989), 32-44; R A Guclich, a w, 1989; idem, "Another look at Markan theology" [Unpublished paper read at the 1989 SNTS-Seminar in Dublin], 1989.

28 H Koester, "From the Kerygma-Gospel to written Gospcls", NTS vol 35 (1989), 361-381.

29 P J J Botha, Die dissipels in die Markusevangelie, Ongepubliseerde DD-Procfskrif, Universiteit van Pretoria, Pretoria 1989.

30 Op die voctsporc van Vorster, JThSA vol 31 (1980); idem, Neotestamentica vol 21(1987).

31 Vgl Kingsbury, $a w, 1983$; Schenke, $a w, 1988$.

$32 \mathrm{Vgl}$ Matcra, $a w, 1982$.

33 Matera, JSNT 34 (1988).

34 Ibid, 3.

35 Ibid, 6.

36 Ibid, 8.

37 Ibid, 14-15.

38 H L Cronis, "The torn veil: Cultus and Christology in Mark 15:37-39", JBL vol 101 (1982), 97-114.

39 Jackson, NTS vol 33 (1987).

40 K Brower, "Elijah in the Markan passion narrative, JSNT vol 18 (1983), 85-101.

41 Ibid, 92-94.

42 Ibid, 94-95.

43 M Hooker, a w (vgl vn 20 hierbo).

44 J Marcus, $Z N W$ vol 80 (1989), 43-46. 
$45 \mathrm{Vg}$ Breytenbach, $a w, 1984,249$; Marcus, $Z N W$ vol 80 (1989), 47.

46 Ibid, 47.

47 Ibid, 55-57 en Breytenbach, a w, 1984,249.

$48 Z N W$ vol 80 (1989), 49-50.

49 Ibid, 1982.

50 Ibid, 104-105.

$51 \quad$ lbid, 106.

52 Ibid, 110.

53 Ibid, 111.

54 Jackson, NTS vol 33 (1987); S Motyer, "The rending of the veil: A Markan Pentecost?", $N T S$ vol 33, (1987), 155-157; Matera, JSNT vol 34 (1988); Van Iersel, $a w, 1988$.

55 Vgl Matera, JSNT vol 34 (1988), 8, 14-15.

56 Motyer, NTS vol 33 (1987), 156.

$57 \quad$ NTS vol 33 (1987), 16.

58 Vgl Breytenbach, $a w 1984,256$.

$59 \quad$ NTS vol 33 (1987), 21.

60 Ibid, 20-21.

61 Ibid, 22.

62 Ibid, 22-24.

63 Ibid, 27.

64 lbid, 31-32.

65 Idem, a w, 1988, 139 (vgl vn 16 hierbo).

66 Ibid, 140-141.

67 Vgl Lührmann, NTS vol 27 (1981).

68 Ibid a w, 464. 
$69 J S N T$ vol 31 (1987).

70 Vgl Breytenbach, a w, 1984, 256.

71 JSNT vol 31 (1987), 8.

72 P G Davis, "Mark's Christological paradox", JSNT vol 35 (1989), 3-18.

73 Ibid, 4.

74 Ibid, 7.

75 Ibid, 9.

76 Ibid, 14.

77 Marcus, NT vol 31 (1989) (vgl vn 21 hierbo).

78 Ibid, 130.

79 Ibid, 135-136.

80 Idem, a w, 1989 ( $\mathrm{vgl}$ vn 21 hierbo).

81 Ibid, 73.

82 J. Marcus, "The time has been fulfilled!' (Mark 1.15)", in Marcus \& Soards, $a$ w, 49-68 (vgl vn 21 hierbo).

83 Ibid, 53.

84 Ibid, 56.

85 Ibid, 59.

86 F Hahn, Christologische Hoheitstitel:Ihre Geschichre in frïhen Christentum, Göttingen 1963.

87 R Pesch, Das Markusevangelium, Freiburg 1977; J Gnilka, Das Evangelium nach Markus, Zürich 1978/9; J Ernst, Das Evangelium nach Markus, Regensburg 1981.

88 Lührmann, $a$ w, 1987, 38, 146-148; Guclich, a w, 1989 (vgl vn. 14), xcxix-xi; idem, SNTS Sem Paper, 1989 (vgl un 26 hierbo).

89 Idem, aw (vgl vn 7 hierbo).

90 J D Kingsbury, "The 'Divine Man' as the key to Mark's Christology - the end of an era?" Interp vol 35 (1981), 243-257. 
91 Idem, WuD NF vol 14 (1977); idem, a w 1987.

92 Idem, NTS vol 32 (1986); ook idem, Christology in context: The earliest Christian response to Jesus, Philadelphia.

93 Idem, a w, 1989.

94 Vgl Jackson NTS vol 33 (1987); Theobald SNTU 13 (1988).

95 Idem, a w, 38,156,264 (vgl vn 9).

96 Ibid, 146.

97 Ibid, 257.

98 "huios", EWNT vol III (1983), 919; "Christos", EWNT vol III (1983), 1154.

99 Hahn, EWNT vol III (1983), 919, 1154.

100 Idem, NTS vol 32 (1986); a w, 1988, 53-70 (vgl vn 91 hierbo).

101 Idem, NTS vol 32 (1986), 322.

102 Idem, $a w, 1988,58$.

103 Ibid, 68.

104 Ibid, 61.

105 Idem, NTS vol 32 (1986), 328.

106 Zmijewski, SNTU vol 12 (1987)(vgl vn 2 hierbo).

107 Idem, a w, 1977.

108 Idem, a w, 1978/9.

109 Idem, a w, 1981.

110 Zmijewski, SNTU vol 12 (1987), 32.

111 Ibid, 34.

112 Idem, SNTU vol 13 (1988).

113 Bv ibid, 39-440.

114 Ibid, 37-38. 
115 Ibid, 45-46.

116 lbid, 40. Vgl. Hahn se verdeling in uitsprake oor die wese en funksie van die Markaanse Jesus.

117 Ibid, 49.

118 Ibid, 56-57, 66 .

119 Ibid, 66. In hierdie opsig is daar groot ooreenkomste tussen die beskouings van Theobald en Jackson, NTS vol 33 (1987).

120 Idem, SNTU vol 13 (1988), 68.

121 Idem, a $w, 1983$ (vgl vn 14 hierbo).

122 Idem, NTS vol 32 (1986) a w, 1988.

123 Vgl Kingsbury, a w, 1983; Matera, JSNT vol 34 (1988).

$124 \mathrm{Vgl}$ Breytenbach, $a w, 1984,255$.

125 Teen Lührmann, $W u D N F$ vol 14 (1977); $a w, 1987$.

126 De Jonge, NTS vol 32 (1986), a w, 1988; Guelich 1989b.

$127 \mathrm{Vgl} \mathrm{J} \mathrm{H} \mathrm{Charlesworth,} \mathrm{"The} \mathrm{concept} \mathrm{of} \mathrm{the} \mathrm{Messiah} \mathrm{in} \mathrm{the} \mathrm{pseudepigrapha",} A N R W$ vol II 19,1 (1984), 188-218; idem, "From Jewish Messianology to Christian Christology: Some caveats and perspectives", in J Neusner, W S Green \& E S Frerichs (eds), Judaism and their Messiahs at the turn of the Christian Era, Cambridge 1987, 225-264.

$128 \mathrm{Vgl}$ egter Jackson, NTS vol 33 (1987); Theobald, SNTU 13 (1988).

129 Vgl K Berger, "Zum traditionsgeschichtlichen Hintergrund christologischer Hoheitstitel", NTS vol 17 (1970/1), 391-425; idem, "Die königlichen Messiastraditionen des Neuen Testaments", NTS vol 20 (1974), 1-44.

$130 \mathrm{Vgl}$ reeds Kingsbury, a w, 1983; Theobald, SNTU vol 13 (1988).

$131 \mathrm{Vgl} J$ Fitzmyer, "The New Testament Title "Son of Man" philologically considered", in idem, A wandering Aramean: Collected Aramaic essays, 143-160, Chico 1979 en 1QapGen 21:13; 11QtgJob 26:2-3; 9:9.

$132 \mathrm{Vgl} \mathrm{G}$ Vermes, "The use of BAR NASH/BAR NASHA in Jewish Aramaic", in idem, Post-biblical studies, Leiden 1975, 147-165 en die vertaling van Gen 4:14 in Neofiti I en Pseudo-Jonathan. Dic probleem is egter dat hierdie tekste baie laat gedateer word en nouliks iets oor die Aramees ten tye van Jesus sê. 
133 Vgl M Black, "Aramaic Barnâshâ and the 'Son of Man", ET vol 95 (1983/4), 200-206.

134 M A Knibb, "The date of the parabols of Enoch: A critical review", NTS vol 25 (1979), 345-395.

135 Vgl Donahue, $C B Q$ vol 48 (1986), 1986; W G Kümmel, Dreißig Jahre Jesusforschung (1950-1980), Bonn 1985, 340-360; Vögtle, a w, 1989 (vgl vn 23 hierbo).

136 Idem, $a w, 1975$.

137 Vgl Fitzmyer $a w, 1979$.

138 Bv Hahn, EWNT III (1983), 927-935.

$139 \mathrm{Vgl}$ Jeremias, Unbekannte Jesusworte, Gütersloh 1967.

140 Idem, a w, 1979.

141 Idem, a w, 1975.

$142 \mathrm{Vg}$ N Perrin, A modem pilgrimage in New Testament Christology, Philadelphia 1974.

143 Idem, a w, 1983, 101-114 (vgl vn 21).

144 Ibid, 17-24.

145 Ibid, 103.

146 Ibid, 105.

147 Vgl ET vol 95 (1983/4); R Bauckham, The Son of Man: 'A man in my position' or 'someone'? JSNT vol 23 (1985), 23-33; Donahue $C B Q$ vol 48 (1986), 494.

148 Idem, a $w, 1987,147-150$.

149 lbid, 1987, 149.

150 Idem, a w, 1974, 84-93,104-121.

$151 \mathrm{Vgl} \mathrm{Kealy,} \mathrm{a} \mathrm{w,} \mathrm{1982,} \mathrm{221-225} \mathrm{(vgl} \mathrm{vn} 1$ hierbo).

152 Idem, $a w, 1988,106-117$ (vgl vn 6 hierbo).

153 Ibid, 112.

154 Idem, a w, 1983 (vgl vn 14 hierbo). 
155 Idem, "Grundzüge markinischer Gottessohn-Christologie", in Anfánge der Christologie (Festschrift für Ferdinand Hahn zum65. Geburtstag, herausgegeben von C Breytenbach \& H Paulsen), Göttingen 1991.

\section{BIBLIOGRAFIE}

Afkortings volgens TRE.

Bauckham, $\mathrm{R}$ 1985. The Son of Man: 'A man in my position' or 'someone'? JSNT 23, 23-33.

Beavis, M A 1987. The trail before the sanhedrin (Mark 14:53-65): Reader response and Greco-Roman readers. $C B Q 49,581-596$.

Berger, K 1970/71. Zum traditionsgeschichtlichen Hintergrund christologischer Hoheitstitel. NTS 17, 391-425.

-- 1974. Die königlichen Messiastraditionen des Neuen Testaments. NTS 20, $1-44$.

Best, E 1989. Mark's narrative technique. JSNT 37, 43-58.

Black C C 1989. The Disciples according to Mark: Markan redaction in current debate. Sheffield: JSOT Press. (JSNT.MS 27.)

Black, M 1983/84. Aramaic Barnâshâ and the 'Son of Man'. ET 95, 200-206.

-- 1986. The theological approbation of the Old Testament by the New Testament. SJTh 39, 1-17.

Boomershine, T E 1974. Mark the storyteller: A rhetorical-critical investigation of Mark's passion and resurrection narrative. Diss. Union Theological Seminary. New York.

Boring, M E 1984. The Christology of Mark: hermeneutical issues for systematic theology. Semeia 30, 124-147.

Botha, P J J 1989. Die dissipels in die Markusevangelie. Diss. Universiteit van Pretoria.

Bravo, C 1984. Marcos: narrativa teológica del conflicto: La respuesta de Dios al pobre (Ensayo de relectura sincronica del relato). Diss. Facultad de teologia, section Francisco de Borja 1984. (Non vidi.)

Brower, K 1983. Elijah in the Markan passion narrative. JSNT 18, 85-101.

Breytenbach, C 1984. Nachfolge und Zukunftserwartung nach Markus: Eine methodenkritische Studie. Zürich: TVZ. (AThANT 71.)

-- 1986. Das Problem des Übergangs von mündlicher zu schriftlicher Überlieferung. Neotestamentica 20, 47-58.

-- [1991]. Grundzüge markinischer Theologie, in Breytenbach \& Paulsen [1991].

Breytenbach, C \& Paulsen, H (Hg.) [1991]. Anfänge der Christologie: 
Festschrift für Ferdinand Hahn zum 65. Geburtstag. Göttingen: Vandenhoeck.

Buby, B 1980. A Christology of relationship in Mark. BTB 10, 149-154.

Charlesworth, J H 1984. The concept of the Messiah in the pseudepigrapha. ANRW II 19,1, 188-218.

-- 1987. From Jewish Messianology to Christian Christology: Some caveats and perspectives, in Neusner, Green \& Frerichs 1987:225-264.

Chouinard, L 1987. Gospel Christology: A study in methodology. JSNT 30, 21-37.

Chronis, H L 1982. The torn veil: Cultus and Christology in Mark 15:37-39. $J B L$ 101, 97-114.

Davis, P G 1989. Mark's Christological paradox. JSNT 35, 3-18.

Dewey, J 1989. Oral methods of structuring narrative in Mark. Interp. 43, 3244.

Donahue, J R 1986. Recent studies on the origin of the "Son of Man" in the Gospels. $C B Q 48,484-498$.

Dormeyer, D 1979. Der Sinn des Leidens Jesu: Historisch-kritische und textpragmatische Analysen zur Markuspassion. Stuttgart: KBW. (SBS 96.)

-- 1987. Die Kompositionsmetapher 'Evangelium Jesu Christi, des Sohnes

Gottes' Mk 1.1: Ihre theologische und literarische Aufgabe in der JesusBiographie des Markus. NTS 33, 452-468.

Ernst, J 1981. Das Evangelium nach Markus. Regensburg: Pustet. (RNT 2.)

Feldmeier, R 1987. Die Krisis des Gottessohnes: Die Gethsemaneerzählung als

Schliüssel der Markuspassion. Tübingen: Mohr. (WUNT II.21.)

Fitzmyer, J A 1979. The New Testament Title "Son of Man" philologically considered, in idem, $A$ wandering Aramean: Collected Aramaic essays, 143-160. Chico, Ca.: Scholars Press. (SBL.MS 25.)

Fowler, R M 1983. Who is "the reader" of Mark's Gospel? SBL Seminar Papers, 31-53.

Fuller, R H 1983. Mark as narrative Christology, in Fuller, R H \& Perkins P (eds.), Who is this Christ?, 67-80, Philadelphia.

Gerhardsson, B 1986. The Gospel Tradition. Lund: Gleerup.

Giesen, H 1983. Christliche Existenz in der Welt und der Menschensohn:

Versuch einer Neuinterpretation des Terminwortes Mk 13,30. SNTU 8, 18-69.

-- 1987. Der Auferstandene und seine Gemeinde: Zum Inhalt und zur

Funktion des ursprünglichen Markusschlusses (16,1-8). SNTU 12, 99-139. Gnilka, J 1978/1979. Das Evangelium nach Markus. Zürich: Benzinger. (EKK II/1-2.) 
Guelich, R A 1989a. Mark 1-8:26. Dallas, Texas: Word Books. (Word Biblical Commentary 34a.)

-- [1989b]. Another look at Markan theology. [Unpublished paper read at the 1989 SNTS-Seminar in Dublin].

Hahn, F Christologische Hoheitstitel:Ihre Geschichte im frühen Christentum.

Göttingen: Vandenhoeck 1963. (FRLANT 83.)

-- 1983a. sv huios, EWNT III.

-- 1983b. sv Christos, EWNT III.

-- (Hg.) 1985. Der Erzähler des Evangeliums: Methodische Neuansätze in der Markusforschung. Stuttgart: KBW. (SBS 118/119.)

Hartman, L 1976. Taufe, Geist und Sohnschaft: Traditionsgeschichtliche Erwägungen zu Mk 1,9-11 par. STNU 1, 89-109.

Hooker, M D 1987. 'What doest thou here, Elijah?': A look at St Mark's account of the transfiguration, in Hurst \& Wright 1987:59-70.

Horsley, R A 1984. Popular Messianic movements around the time of Jesus. $C B Q 46,471-495$.

-- 1985. "Like one of the prophets of old": Two types of popular prophets at the time of Jesus. $C B Q 47,435-463$.

Hurst, L D \& Wright, N T (eds.) 1987. The glory of Christ in the New Testament: Studies in Christology: In memory of George Bradford Caird. Oxford: Clarendon Press.

Iersel, B M F van 1983. Locality, structure and meaning in Mark. LingBibl 53, 445-54.

-- 1988. He will baptize you with Holy Spirit (Mark 1,8): The time perspective of baptisei, in Baarda,T et al (eds.), Text and testimony: Essays on the New Testament and Apocryphal Literature in honour of $A F J$ Klijn Seiten!. Kampen: J H Kok.

-- 1989. Reading Mark. London: T\&T Clark.

Jackson, H M 1987. The death of Jesus in Mark and the miracle from the cross. NTS 33, 16-37.

Johnson, E S Jr. 1987. Is Mark 15.39 the key to Mark's Christology? JSNT 31, 3-22.

Jonge, $\mathrm{M}$ de 1986. The earliest use of Christos. Some suggestions. NTS 32, 321-343.

-- 1988. Christology in context: The earliest Christian response to Jesus. Philadelphia: Westminister Press.

Kealy, S P 1982. Mark's gospel: $A$ history of its interpretation: From the beginning until 1979. New York: Paulist Press.

Kingsbury, J D 1981. The "Divine Man" as the key to Mark's Christology - the 
end of an era? Interp. 35, 243-257.

-- 1983. The Christology of Mark's Gospel. Philadelphia: Fortress Press.

Klauck, H J 1982. Die erzählerische Rolle der Jünger im Markusevangelium. NT 24, 1-26.

Klein, H 1987. Das Bekenntnis des Petrus und die Anfänge des Christusglaubens im Urchristentum. EvTh 47, 176-192.

Knibb, M A 1979. The date of the parabols of Enoch: A critical review. NTS 25, 345-395.

Koch, D A, Sellin, G \& Lindemann, A (Hg.) 1989. Jesu Rede von Gott und ihre Nachgeschichte im frühen Christentum: Beiträge zur Verkündigung Jesu und zum Kerygma der Kirche: Festschrift für Willi Marxsen zum 70. Geburtstag. Güthersloh: Gerd Mohn.

Koester, H 1989. From the Kerygma-Gospel to written Gospels. NTS 35, 361381.

Kümmel, W G 1985. Dreißig Jahre Jesusforschung (1950-1980). Bonn: Peter Hanstein. (BBB 60.)

Lindars, B 1983. Jesus Son of Man: A fresh examination of the Son of Man sayings in the Gospels in the light of recent research. London: SPCK.

Lindemann, A [1991]. Die Erzählung der Machttaten Jesu, in Breytenbach \& Paulsen [1991].

Lührmann, D 1977. Biographie des Gerechten als Evangelium: Vorstellungen zu einem Markus-Kommentar. $W u D N F$ 14, 25-50.

-- 1981. Markus 14. 55-64: Christologie und Zerstörung des Tempels im Markusevangelium. NTS 27, 457-474.

-- 1987. Das Markusevangelium. Tübingen: Mohr. (HNT 3.)

Magness, J L 1986. Sense and absence: Structure and suspension in the ending of Mark's Gospel. Alanta: Scholars Press.

Malborn, E S 1983. Fallable Followers: Women and men in the Gospel of Mark, Semeia 28, 29-48.

-- 1986. Disciples/Crowds/Whoever: Markan characters and readers. NT 28, 104-130.

Marcus, J. 1986. The mystery of the kingdom of God. Atlanta, Georgia: Scholars Press. (SBLDS 90.)

-- 1989a. Mark 9,11-13: "As it has been written". ZNW 80, 42-63.

-- 1989b. Mark 14:61: "Are you the Messiah-Son-of-God?". NT 31, 125-141.

-- 1989c. 'The time has been fulfilled!' (Mark 1.15), in Marcus \& Soards 1989:49-68.

Marcus, J \& Soards, M L (eds.) 1989. Apokalyptic and the New Testament: Essays in honour of J. Louis Martyn. Sheffield: JSOT Press. (JSNT.S 24.) 
Matera, F J 1982. The kingship of Jesus: Composition and theology in Mark 15. Chico, Ca.: Scholars Press. (SBLDS 66.)

-- 1988. The prologue as the interpretative key to Mark's gospel. JSNT 34, 320.

Motyer, S 1987. The rending of the veil: A Markan Pentecost? NTS 33, 155157.

Muddiman, J 1987. The glory of Jesus, Mark 10:37, in Hurst \& Wright 1987:51-58.

Neusner, J, Green, W S \& Frerichs, E S (eds.) 1987. Judaism and their Messiahs at the turn of the Christian Era. Cambridge: University Press.

Perrin, N 1974. A modern pilgrimage in New Testament Christology. Philadelphia: Fortress Press.

Pesch, R 1977. Das Markusevangelium. Freiburg: Herder. (HThK II.)

Rebell, W 1989. 'Sein Leben Verlieren' (Mark 8.35 Parr.) als Strukturmoment vor- und nachösterlichen Glaubens. NTS 35, 202-218.

Rhoads D \& Mitchie D 1982. Mark as Story: An introduction to the narrative of a Gospel. Philadelphia: Fortress Press.

Scharberg, J 1989. Mark 14,62: Early Christian Merkabah Imagery?, in Marcus \& Soards 1989:69-94.

Schenke, L 1988. Das Markusevangelium. Stuttgart: Kohlhammer.

Sellin, G 1983. Textlinguistische und semiotische Erwägungen zu Markus 4,134. NTS 29, 508-530.

-- 1989. Einige symbolische und esoterische Züge im Markus-Evangelium, in Koch et al 1989:74-90.

Söding, T 1985. Glaube bei Markus. Stuttgart: KBW. (SBB 12.)

Theobald, M 1988. Gottessohn und Menschensohn. Zur polaren Struktur der Christologie im Markusevangelium. SNTU 13, 37-97

Van Eck, E 1988. Galilea en Jerusalem as narratologiese ruimtes in die Markusevangelie: 'n kontinuering van die Lohmeyer-Lightfoot-Marxsen ketting. HTS 44, 139-163.

Vermes, G 1975. The use of BAR NASH/BAR NASHA in Jewish Aramaic, in idem, Post-biblical studies, 147-165. Leiden: Brill. (StJLA 8.)

Vögtle, A 1989. Eine überholte "Menschensohn"-Hypothese? in Aland, K \& Meurer, S (Hg.), Wissenschaft und Kirche: Festschrift für E Lohse, 70-95. Bielefeld: Luther-Verlag.

Vorster, W S 1980a. Mark: Collector, redactor, author, narrator? JThSA 31, 46-61.

-- 1980b. Die Evangelie volgens Markus: Inleiding en teologie, in du Toit, A B (red), Handleiding by die Nuwe Testament, IV: Die Sinoptiese 
Evangelies en Handelinge: Inleiding en teologie, 109-155. Pretoria: NG Kerkboekhandel.

-- 1986. The New Testament and narratology. JILS/TLW 2, 52-62.

-- 1987. Characterization of Peter in the Gospel of Mark. Neotestamentica 21, 57-76.

-- 1988. Oor die Nuwe Testament, vertelkunde en prediking. HTS 44, 164177.

Wrede, W 1901. Das Messiasgeheimnis in den Evangelien. Göttingen: Vandenhoeck.

Zmijewski, J 1987. Die Sohn-Gottes-Prädikation im Markusevangelium: Zur Frage einer eigenständigen markinischen Titelchristologie. SNTU 12, 534.

Zwick, R 1989. Montage im Markusevangelium: Studien zur narrativen Organisation der ältesten Jesuserzählung. Stuttgart: KBW. (SBB 18. 